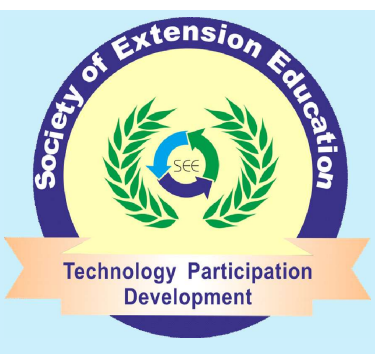

Research Note

\section{Indian Research Journal of Extension Education}

ISSN: 0972-2181 (Print), 0976-1071 (Online)

NAAS Rating : 5.22

Journal homepage: seea.org.in

https://doi.org/10.54986/irjee/2022/jan_mar/114-117

\title{
Constraint Perceived by Osmanabadi Goat Keepers in Latur Region of Maharashtra State
}

\author{
Abhishek Randhave ${ }^{1}$, Narendra Khode ${ }^{2}$ and Sharad Avhad ${ }^{3}$ \\ 1. M.V. Sc. Scholar, 2\&3. Asstt. Prof., (Ext. Edu.), 4. Asstt. Prof. (Vet. Sc.), CV\&ASc., Udgir, Latur, Maharashtra \\ Corresponding author e-mail : khodenarendra@gmail.com \\ Paper Received on August 05, 2021, Accepted on Novembe 22, 2021 and Published Online on January 01,2022
}

\begin{abstract}
A present ex-post-facto study was conducted to identify the perceived constraints of Osmanabadi goat keepers in the Latur region. A total of 120 goat keepers were equally selected across Latur and Osmanabad districts using the multistage random sampling technique. The data was collected by personal interview method using a pre-tested semi-structured interview schedule. The study revealed that kid mortality, lack of financial support, and nonavailability of insurance facilities were the major perceived constraints of overall Osmanabadi goat-keeping households. Among small goat keepers, kid mortality and lack of breeding bucks were significantly greater perceived constraints than medium goat keepers. Higher labor wages and non-availability of grazing land were severely perceived limitations of medium goat keepers, whereas fodder scarcity to large goat keepers. Small, medium, and large Osmanabadi goat keepers of the Latur region need constraints-specific interventions through veterinary institutes or relevant extension agencies to examine and address varied perceived constraints.
\end{abstract}

Key words: Constraint; Osmanabadi goat; Goat rearing; Kid mortality.

As a small ruminant, the goat plays a vital role in the food and nutritional security of under privileged rural families. The role of small ruminants is more pronounced in the arid and semi-arid zone of the country, where the risk and uncertainty of crop failure are high (Yadav et al., 2018). Goat rearing is one of the most widely adopted livestock activities in the semi-arid Latur region. Latur region, comprised of Osmanabad, Latur, Hingoli, and Nanded districts, possessed almost 21 per cent of Osmanabadi goats of Maharashtra. Osmanabad and Latur districts are the home tract of Osmanabadi goat and had around 94 per cent of Osmanabadi goat population of the Latur region $(A H D, 2007)$. Traditional goat rearing is presumed to face many hurdles that hinder the adoption of scientific goat management practices and the profitability of goat rearing activity. Region to region constraints is different. Lack of grazing land (Braj et al. 2009), lower sale price (Rajkumar et al. 2014), lack of pure breed buck (Jana et al. 2014) were the major constraints of goat keepers reported in their study area. With this background, the present study was conducted to explore Osmanabadi goat keepers' perceived constraints in the Latur region and suggest practical implications to overcome limitations.

\section{METHODOLOGY}

The present ex-post-facto study was conducted purposively in the most Osmanabadi goat-populated Osmanabad and Latur districts in Maharashtra. The multistage random sampling technique was used, and in 
the first stage, two talukas were selected randomly from each district viz. Bhum and Umerga (Osmanabad district), Ahmedpur and Udgir (Latur district). Then, five villages from each taluka and six Osmanabadi goatkeeping households were randomly selected from each village. The person, who had control over the decision and operations of the goat farm, was the respondent. Thus, a total of 120 goat keepers were the sample size for the study. Commonly felt 15 constraints listed out through literature and expert's opinion. The responses were collected on a four-point continuum viz. 'most serious', 'serious', 'least serious' and 'at all not serious' with respective assigned codes $4,3,2$, and 1 . The goatkeeping constraint levels were measured based on 'constraint index (CI)' with score ranges from minimum 15 to maximum 60 .

$$
\mathrm{CI}=\frac{\text { Total constrants score obtained }}{\text { Max. obtainable score }} \times 100
$$

The field survey was conducted during DecemberJanuary, 2020-2021 to collect data through personal interviews using a pre-tested semi-structured interview schedule. After the collection of data, these respondents were further grouped (Table 1) into small $(2-5.35$ Standard Goat Unit), medium (5.35 - 8.70 SGU), and large (8.70 - 18.75 SGU) Osmanabadi goat keepers using cumulative square root frequency method. The standard goat unit was worked out by assigning one SGU to each adult doe and buck, $1 / 2$ SGU to each kid that had an age between 3 to 6 months, and $1 / 4$ SGU to each young kid below three months of age.

\section{RESULTS AND DISCUSSION}

Results shown in Table 1 elicited that mortality of kids was the most serious constraint perceived by 80.00 per cent medium, three-fourth large, and 57.89 per cent small goat keepers in the study area. Kid mortality was demonstrated as a major constraint (Sabapara, 2016; Sandhu, 2017 and Raja et al., 2018)] in goat rearing. Kid mortality had a direct influence over returns, and therefore it might be why they perceived it as the most serious constraint. Other highly ranked constraints involved lack of credit facility or financial support (MS 3.47), non-availability of insurance facility (MS 3.45), and higher labor wages (MS 3.27). Woode (2013) and Mandavkar et al. (2015) had reported that lack of credit facility/financial support for goat farmers was the major hurdle. Non-availability of labor was the most serious constraint of the majority across all groups of goat keepers, while disease occurrence and lack of breeding buck were serious constraints. Half of the large and small goat keepers perceived lack of training facility as a serious constraint, while most $(48.00 \%)$ of medium goat keepers perceived it as the most serious constraint. Scarcity of fodder, lack of veterinary health facilities, and non-availability of grazing land were the most serious constraints among small goat keepers. Similar observations were reported by Braj et al. (2009), Tanwar (2011), Kumar et al. (2011), Rajkumar et al. (2014), Mandavkar et al. (2015), and Paul et al. (2020). Mortality in adult goats, the lower market price of goat, lower price for goat milk, and prestige associated with goat rearing activity were either perceived as less serious or not serious at all by the overall maximum proportion of goat keepers. The findings contradicted with Kumar et al. (2011), Jana et al. (2014), and Rajkumar et al. (2014). Osmanabadi goat keepers in the study area were satisfied in realizing better prices for goat sold.

One-way analysis of variance (Table 2) showed a statistically significant difference between means of perceived seriousness about constraints viz. kid mortality, higher labor wages, fodder scarcity, nonavailability of grazing land, and lack of breeding buck across small, medium, and large Osmanabadi goat keepers. Application of Tukey post-hoc analysis revealed significant pairwise mean differences between small and medium goat keepers about constraints viz. kid mortality, higher labor wages, non-availability of grazing land, and lack of breeding buck, with an average difference of $0.438,0.513,0.496$, and 0.588 , respectively. Perceived seriousness about fodder scarcity constraint was elicited significant pairwise mean difference $(0.676)$ between small and large goat keepers. It implies that perceived seriousness about kid mortality and lack of breeding buck was significantly higher among small goat keepers than medium goat keepers. Higher labor wages and nonavailability of grazing land were perceived as significantly more serious constraints by medium goat keepers than small goat keepers. Fodder scarcity was the significantly higher perceived constraint of large goat keepers compared to small goat keepers.

Further, the respondents were grouped into 'low' (48.33-63.67), 'medium' (63.67-71.33), and 'high' (71.33-86.67) level categories perceiving constraints as 
Table 1. Perceived seriousness of constraints by Osmanabadi goat keepers

\begin{tabular}{|c|c|c|c|c|c|c|c|c|c|c|c|c|c|c|}
\hline \multirow{2}{*}{ Perceived constraints } & \multicolumn{4}{|c|}{ Small $(n=38)$} & \multicolumn{4}{|c|}{$\operatorname{Medium}(\mathrm{n}=50)$} & \multicolumn{4}{|c|}{ Large $(n=32)$} & \multirow{2}{*}{ MS* } & \multirow{2}{*}{ Rank } \\
\hline & MS & $\mathrm{S}$ & LS & NS & MS & $\mathrm{S}$ & LS & NS & MS & $\mathrm{S}$ & LS & NS & & \\
\hline Mortality of kids & 57.89 & 21.05 & 18.42 & 2.64 & 80.00 & 18.00 & 2.00 & 0.00 & 75.00 & 15.63 & 9.37 & 0.00 & 3.61 & I \\
\hline Lack of credit facility & 63.16 & 26.32 & 7.89 & 2.63 & 60.00 & 26.00 & 12.00 & 2.00 & 53.13 & 40.63 & 6.24 & 0.00 & 3.47 & II \\
\hline Non-availability of insurance & 68.42 & 18.42 & 13.16 & 0.00 & 52.00 & 40.00 & 4.00 & 4.00 & 50.00 & 40.63 & 9.37 & 0.00 & 3.45 & III \\
\hline Higher labor wages & 68.42 & 23.68 & 2.64 & 5.26 & 44.00 & 32.00 & 8.00 & 16.00 & 53.13 & 25.00 & 18.75 & 3.12 & 3.27 & IV \\
\hline Lack of training facility & 36.84 & 50.00 & 10.53 & 2.63 & 48.00 & 44.00 & 6.00 & 2.00 & 31.25 & 50.00 & 18.75 & 0.00 & 3.26 & $\mathrm{~V}$ \\
\hline Non-availability of labor & 63.16 & 23.68 & 5.27 & 7.89 & 44.00 & 34.00 & 6.00 & 16.00 & 53.13 & 21.88 & 15.63 & 9.36 & 3.21 & VI \\
\hline Disease occurrence & 28.95 & 63.16 & 7.89 & 0.00 & 32.00 & 58.00 & 10.00 & 0.00 & 31.25 & 53.13 & 12.50 & 3.12 & 3.19 & VII \\
\hline Scarcity of fodder & 52.63 & 39.47 & 2.64 & 5.26 & 42.00 & 44.00 & 4.00 & 10.00 & 31.25 & 28.13 & 21.88 & 18.74 & 3.13 & VIII \\
\hline Lack of vet. facility & 52.63 & 21.05 & 15.79 & 10.53 & 42.00 & 30.00 & 20.00 & 8.00 & 40.63 & 50.00 & 0.00 & 9.37 & 3.13 & IX \\
\hline Lack of grazing land & 50.00 & 39.47 & 2.64 & 7.89 & 20.00 & 58.00 & 6.00 & 16.00 & 28.13 & 40.63 & 12.50 & 18.74 & 2.97 & $\mathrm{X}$ \\
\hline Lack of breeding buck & 5.26 & 44.74 & 7.89 & 42.11 & 8.00 & 70.00 & 8.00 & 14.00 & 6.25 & 56.25 & 3.12 & 34.38 & 2.43 & $\mathrm{XI}$ \\
\hline Mortality of adult goats & 7.89 & 39.47 & 50.00 & 2.64 & 4.00 & 22.00 & 70.00 & 4.00 & 15.63 & 25.00 & 56.25 & 3.12 & 2.42 & XII \\
\hline Lower price for goat & 7.89 & 13.16 & 50.00 & 28.95 & 4.00 & 16.00 & 44.00 & 36.00 & 15.63 & 6.24 & 34.38 & 43.75 & 1.93 & XIII \\
\hline Lower price for goat milk & 7.89 & 7.89 & 50.00 & 34.22 & 4.00 & 10.00 & 48.00 & 38.00 & 15.63 & 6.24 & 37.50 & 40.63 & 1.88 & XIV \\
\hline Lower prestigious business & 2.64 & 5.26 & 23.68 & 68.42 & 4.00 & 22.00 & 14.00 & 60.00 & 0.00 & 31.25 & 6.25 & 62.50 & 1.61 & $\mathrm{XV}$ \\
\hline
\end{tabular}

MS-Most Serious; S-Serious; LS-Least Serious and NS- At all not serious; MS*=Mean Score

Table 2. Multiple comparisons showing mean differences between small, medium and large Osmanabadi goat keepers

\begin{tabular}{|c|c|c|c|c|c|c|c|c|c|c|c|}
\hline \multirow[t]{3}{*}{ Perceived Constraints } & \multirow{2}{*}{\multicolumn{3}{|c|}{$\begin{array}{r}\text { Small goat keepers }(n=38) \\
\text { Mean differences }\end{array}$}} & \multirow{2}{*}{\multicolumn{4}{|c|}{$\begin{array}{c}\text { Medium goat keepers }(\mathrm{n}=50) \\
\text { Mean differences }\end{array}$}} & \multicolumn{4}{|c|}{ Large goat keepers $(n=32)$} \\
\hline & & & & & & & & \multicolumn{2}{|c|}{ Mean differences } & \multirow{2}{*}{$\begin{array}{l}\text { F- } \\
\text { value }\end{array}$} & \multirow[t]{2}{*}{ Sig. } \\
\hline & Mean & $\begin{array}{l}\text { Medium } \\
(\mathrm{n}=50)\end{array}$ & $\begin{array}{l}\text { Large } \\
(\mathrm{n}=32)\end{array}$ & Mean & $\begin{array}{l}\text { Small } \\
(\mathrm{n}=38)\end{array}$ & $\begin{array}{l}\text { Large } \\
(\mathrm{n}=32)\end{array}$ & Mean & $\begin{array}{l}\text { Small } \\
(\mathrm{n}=38)\end{array}$ & $\begin{array}{l}\text { Medium } \\
(\mathrm{n}=50)\end{array}$ & & \\
\hline Mortality of kids & 3.34 & $-0.438 *$ & -0.314 & 3.78 & $0.438^{*}$ & 0.124 & 3.66 & 0.314 & -0.124 & & .011 \\
\hline Lack of credit facility & 3.50 & 0.060 & 0.031 & 3.44 & -0.060 & -0.029 & 3.47 & -0.031 & 0.029 & 0.071 & .931 \\
\hline Lack of insurance facility & 3.55 & 0.153 & 0.146 & 3.40 & -0.153 & -0.006 & 3.41 & -0.146 & 0.006 & 0.561 & .572 \\
\hline Higher labor wages & 3.55 & $0.513^{*}$ & 0.271 & 3.04 & $-0.513 *$ & -0.241 & 3.28 & -0.271 & 0.241 & $3.143 *$ & .047 \\
\hline Lack of training facility & 3.21 & -0.169 & 0.086 & 3.38 & 0.169 & 0.255 & 3.13 & -0.086 & -0.255 & 1.370 & .258 \\
\hline Non-availability of labor & 3.42 & 0.361 & 0.234 & 3.06 & -0.361 & -0.127 & 3.19 & -0.237 & 0.127 & 1.370 & .258 \\
\hline Disease occurrence & 3.21 & -0.009 & 0.086 & 3.22 & 0.009 & 0.095 & 3.13 & -0.086 & -0.095 & 0.237 & .790 \\
\hline Scarcity of fodder & 3.39 & 0.215 & $0.676^{*}$ & 3.18 & -0.215 & 0.461 & 2.72 & $-0.676^{*}$ & -0.461 & $4.659 *$ & .011 \\
\hline Lack of vet. health facility & 3.16 & 0.098 & -0.061 & 3.06 & -0.098 & -0.159 & 3.22 & 0.061 & & 0.276 & .759 \\
\hline Lack of grazing land & 3.32 & $0.496^{*}$ & 0.535 & 2.82 & $-0.496 *$ & 0.039 & 2.78 & -0.535 & -0.039 & $3.720 *$ & .027 \\
\hline Lack of breeding buck & 2.13 & $-0.588 *$ & -0.212 & 2.72 & $0.588^{*}$ & 0.376 & 2.34 & 0.212 & -0.376 & $4.334 *$ & .015 \\
\hline Mortality of adult goats & 2.53 & 0.266 & -0.005 & 2.26 & -0.266 & -0.271 & 2.53 & 0.005 & 0.271 & 2.236 & .111 \\
\hline Lower price for goat & 2.00 & 0.120 & 0.063 & 1.88 & -0.120 & -0.058 & 1.94 & -0.063 & 0.058 & 0.188 & .829 \\
\hline Lower price for goat milk & 1.89 & 0.095 & -0.074 & 1.80 & -0.095 & -0.169 & 1.97 & 0.074 & 0.169 & 0.365 & .695 \\
\hline Lower prestigious business & 1.42 & -0.279 & -0.266 & 1.70 & 0.279 & 0.012 & 1.69 & 0.266 & -0.012 & 1.261 & .287 \\
\hline
\end{tabular}

Mean difference is significant at the 0.05 level

Table 3. Extent of perceived constraints in Osmanabadi goat rearing

\begin{tabular}{lcccc}
\hline Extent of constraints (Index) & Small $(\mathrm{n}=38)$ & Medium $(\mathrm{n}=50)$ & Large $(\mathrm{n}=32)$ & Pooled $(\mathrm{N}=120)$ \\
\hline Low $($ Score $48.33-63.67)$ & $03(07.89)$ & $11(22.00)$ & $07(21.88)$ & $21(17.50)$ \\
Medium $(63.67-71.33)$ & $10(26.32)$ & $12(24.00)$ & $10(31.25)$ & $32(26.67)$ \\
High $(71.33-86.67)$ & $25(65.79)$ & $27(54.00)$ & $15(46.88)$ & $67(55.83)$ \\
Mean \pm SE & $72.72 \pm 1.15$ & $71.23 \pm 1.26$ & $70.73 \pm 1.16$ & $71.57 \pm 0.71$ \\
\hline
\end{tabular}

One-way ANOVAF (2) $=0.649, \mathrm{P}=0.525$; Figures in parenthesis indicates percentage. 
serious using constraint index and cumulative square root frequency method (Table 3). It depicted that majority of 'pooled' goat keepers (55.83\%) perceived constraints in goat farming to a great extent, followed by medium (26.67\%) and low (17.50\%) levels. A relatively larger proportion of small goat keepers perceived constraints at a greater extent than medium and large goat keepers, but statistically, there was no significant difference across the group. Overall mean values of constraint indices resulted in that small, medium, and large goat keepers were similar in their perception of goat rearing constraints.

\section{CONCLUSION}

Overall, mortality of kids, lack of financial support, and non-availability of insurance facilities were the major perceived constraints of Osmanabadi goat-keeping households. Kid mortality and lack of breeding bucks were significant constraints of small goat keepers than medium goat keepers. Higher labor wages and nonavailability of grazing land were severely perceived limitations of medium goat keepers, whereas fodder scarcity to large goat keepers. The majority of Osmanabadi goat keepers perceived constraints in goat farming at a higher (71.33-86.67 indices) extent. Small, medium, and large goat keepers had varied seriousness over different constraints. Therefore, constraintsspecific interventions through veterinary institutes or relevant extension agencies are needed to examine and address varied perceived constraints of Osmanabadi goat keepers belonging to the Latur region.

\section{CONFLICTS OF INTEREST}

The authors declare that they have no conflicts of interest.

\section{REFERENCES}

AHD (2007). Statement showing the district wise and breed wise number of goats in the state as per Livestock Census 2007 (Provisional) (Accessed through https://ahd.maharashtra.gov.in/population viewed on 12.11.2020).

Braj, M; Sagar, R. L. and Singh, K. (2009). Factors related to promotion of scientific goat farming. Indian J. Ext. Edu., $9(3): 47-50$.

Jana, C.; Rahman, F.H.; Mondal, S.K. and Singh, A.K. (2014). Management practices and perceived constraints in goat rearing in Burdwan district of West Bengal. Indian J. Ext. Edu., 14 (1) : 107-110.

Kumar, S.; Rama Rao, C.A.; Kareemulla, K. and Venkateswarlu, B. (2011). Role of goats in livelihood security of rural poor in the less favoured environments. Indian J. Agri. Eco., 65 (4) : 761-781.

Mandavkar, P. M.; Hanmante, A. A. and Talathi, M. S. (2015). Status of goat farming practices, knowledge and adoption status of technologies in North Konkan coastal zone of Maharashtra. J. Krishi Vigyan, 3 (2) : 93-96.

Paul, A. K.; Sultana, M. J. and Nasrin, F. (2020). Management practices, reproductive performance and constraints of goat rearing in Bangladesh. Indian J. of Small Rumi. (The), 26 (1) : 138-141.

Raja, T.; Prabu, M.; Pandian, A. and Thirunavukkarasu, P. (2018). Factors influencing the constraints perceived by the smallscale backyard goat farmers. Intl. J. Livestock Res., 8 (12) : 175-181.

Rajkumar, N. V. and Kavithaa, N. V. (2014). Constraints in goat farming perceived by farm women in Erode district of Tamilnadu. Intl. J. of Sci., Envir. and Tech., 3 (1) : 116-122.

Sabapara, G. P. (2016). Socio-economic profile of goat rearers and marketing practices of goats in Southern Gujarat, India. Livestock Res. Intl., 4 (2) : 83 -87.

Sandhu, S. S. (2017). Studies on goat management practices under field conditions in South West Punjab. Ph.D. Thesis (unpub.) submitted to Guru Angad Dev Veterinary and Animal Sciences University, Ludhiana (Panjab).

Tanwar, P. S. (2011). Constraints perceived by goat keepers in adoption of goat husbandry practices in semi-arid Rajasthan. $J$. Comm. Mobi.and Sust. Dev., 6 (1): 108-111.

Woode, G. (2013). An analysis of the goat value-chain as a strategy for poverty reduction in Ghana. Accessed through https:/ /d1wqtxts1xzle7.cloudfront.net/41484063. [Viewed 16 December 2020] Pp 27.

Yadav, C. M. and Pareek, O. P. (2018). Livestock holding and its association of different variables of Sonadi sheep in its native tracts. Indian J. Ext. Edu., 18 (1) : 11-14. 